This is a self-archived version of an original article. This version may differ from the original in pagination and typographic details.

Author(s): Kouri, Suvi

Title: Finnish Military Officer Identities and Micro-Political Resistance

Year: 2022

Version: Published version

Copyright: (C) The Author(s) 2021

Rights: $C C$ BY 4.0

Rights url: https://creativecommons.org/licenses/by/4.0/

Please cite the original version:

Kouri, S. (2022). Finnish Military Officer Identities and Micro-Political Resistance. Armed Forces and Society, 49(1), 160-178. https://doi.org/10.1177/0095327x211054116 


\title{
Finnish Military Officer Identities and Micro-Political Resistance
}

Armed Forces \& Society

202I, Vol. 0(0) I-19

(C) The Author(s) 2021

\section{(c) (i)}

Article reuse guidelines: sagepub.com/journals-permissions DOI: I0.II77/0095327X2II054II6 journals.sagepub.com/home/afs @SAGE

\section{Suvi Kouri ${ }^{1}$}

\begin{abstract}
Drawing on the concept of micro-political resistance, this article presents an empirical analysis of how officers of the Finnish Defence Forces challenge, resist, and reinforce the collective military identities constructed within the prevailing organizational discourses. There is a need for identity work to meet the norms and ideals of the military, but individuals can also work as change agents. Micro-political resistance derives from feelings of otherness as well as conflict between the dominant organizational identities and individuals' personal interests. This study presents a thematic discourse analysis based on texts written by 108 officers and 12 interviews on the theme of "the ideal soldier." Three main discourses of micro-political resistance were identified: perceiving the profession of a military officer as a job like any other rather than a sacred calling, putting family first, and being oneself instead of embodying the traditional masculine ideal soldier.
\end{abstract}

\section{Keywords}

military organization, gender issues, ideal soldier, identity work, military identity, micro-political resistance

\footnotetext{
'Faculty of Humanities and Social Sciences, Department of Social Sciences and Philosophy, University of Jyväskylä, Finland

\section{Corresponding Author:}

Suvi Kouri, Faculty of Humanities and Social Sciences, Department of Social Sciences and Philosophy, University of Jyväskylä, PO Box 35, Jyvaskyla 400 I4, Finland.

Email: suvi.kouri@gmail.com
} 
An institution is legitimated in terms of values and norms: that is, a purpose transcending individual self-interest in favor of a presumed higher good (Moskos, 1977, p. 42).

\section{Introduction}

According to Moskos et al. (2000), one of the features of what social theorists refer to as the postmodern age is a decreasing consensus about what the public good might be and what values it entails. People are less willing to defer to authorities and more eager to question old truths, often sustained by traditional institutions (Moskos et al., 2000). In terms of military institutions, this development not only affects civil-military relations but also challenges the power of the organizational regulation of military identities. In this study, the concept of micro-political resistance (Davies \& Thomas, 2004) is employed to examine discursive forms of resistance, that is, resistance at the level of identities and meanings, as Thomas et al. (2004) phrase it. This study provides insight into the ways in which military officers of the Finnish Defence Forces (FDF) contest organizational identities constructed within the prevailing discourses. Prevailing discourses refer to the social power and control practiced by an organization over the actions and minds of its members (van Dijk, 1996). The concept of micro-political resistance can be defined as subtle forms of disruption in an organizational setting. This derives from feelings of difference and otherness and conflict between the dominant organizational identities and individuals' personal interests (van Dijk, 1996).

According to Woodward and Jenkings (2011), traditional military sociological research has paid limited attention to the soldier at the individual level and the conceptualization of individual identity. Even though the military is considered a total institution (Goffman, 1961), it is important to acknowledge that individuals are not passive entities who submit to organizational control and construct their identities accordingly. Individuals are creative agents who shape the organizations they inhabit (Collinson, 2003). This study aims to contribute to the understanding of how power, subjectivity, and agency are negotiated within the rigid framework of a military institution and how individual identities may further the process of change within an organizational culture.

Regardless of voluntary subjection to certain forms of organizational control, military officers' identity work is an ongoing process. Military identities are not fixed but are subject to change (Kümmel, 2018). Identities, in general, are socially constituted and expressed (Woodward \& Jenkings, 2011). They are contingent and shaped by time and space (Woodward \& Jenkings, 2011). This study aims to address the following questions:

1) What kinds of discourses of micro-political resistance can be identified among FDF officers?

2) What kinds of possibilities does micro-political resistance create to practice soldiering when the officers' personal identities and the dominant organizational identities are in conflict? 
First, the article begins with a short review of the literature on military identities and how identities are affected by the process of constant change within postmodern militaries. Second, the features of Finnish military officer identities are mapped. Following this, the approach of micro-political resistance used as a theoretical and conceptual framework in this study is presented. The subsequent sections present the method of thematic discourse analysis and the data, consisting of 108 texts and 12 interviews with military officers working in the FDF. The findings section introduces the prevailing discourse of the greater good and three discourses of micro-political resistance: 1) perceiving the profession of a military officer as a job like any other, 2) putting family first, and 3) being oneself.

\section{Military Identities in Motion}

Identity theory (IT) has been developed over the past 50 years (Stets et al., 2020). According to IT (Stets et al., 2020), identities are organized in salience hierarchy. Identity salience means the probability of an identity being activated across situations. Stryker (2002 [1980], p. 84) states: "The greater the commitment, the higher the identity salience, the higher the probability that role performance will reflect institutionalized values and norms." The salience hierarchy of identities is not established, but identities may move up and down within the hierarchy. The salience hierarchy of identities and its dynamic nature may help to understand the constant negotiation of soldierly subjects aiming to find a balance between organizational and personal values, roles, and identities.

The construction and formation of military identities are, to a certain extent, influenced by the organization through socialization and training (Kümmel, 2018). According to Kümmel (2018), military organizations have specific role expectations for each individual soldier. The goal of the process of socialization is to internalize these expectations. However, the individual soldier may resist organizational identities, at least in part, and feel that they conflict with their personal identity (Kümmel, 2018). Castells (2010) argues that collective professional identities are becoming more fragile and are being replaced by personal identity work and different ways of practicing a profession. According to Norheim-Martinsen (2016), the image of the military as a "unique organizational entity" needs to be updated. Norheim-Martinsen (2016) states that the security sectors in Europe are becoming increasingly like "normal" organizations with the same dynamics and demands as other public and private organizations. Over the last 20 years, change has become a normal state for European armed forces (Norheim-Martinsen, 2016).

When the objective of the militaries was narrowly defined as defending the national territory, the competence requirements for soldiers were mainly related to combat fighting, and their identity followed the ideals of a warrior (Kümmel, 2018). One of the most well-known findings in military sociology is the shift from the combat leader in the early modern period to the managerial technician in the late modern period as the dominant type of military professional (Janowitz, 1960). Postmodern militaries, as 
described by Moskos et al. (2000), need a more versatile professional soldier. According to Kümmel (2018, p. 488), they are in search of a hybrid soldier: "He/she is a warrior and a fighter as well as a constable, a policeman, a diplomat and an armed global street worker." The postmodern professional military officer is required not only to understand the realities of war and combat fighting but also to have knowledge of the local culture when working abroad, language and negotiation skills, the ability to cooperate with both military and civilian actors, social skills, and empathy (Kümmel, 2018).

Despite changes in warfare and organizational culture, as well as the new demands and expectations of a postmodern soldier, studies have shown that military organization and military identities also resist change (e.g., Do \& Samuels, 2020; Holmberg \& Alvinius, 2019; Pendlebury, 2020). Holmberg and Alvinius (2019) argue that certain elements of military organizational characteristics may inhibit some change processes that are expected by the state and public opinion. The so-called normative pressures in terms of changes in values and normalization especially challenge the bureaucratic, hierarchical, narcissistic, and greedy traits of military organizations. Pendlebury (2020) argues that the basis of a dominant identity is rarely questioned in the military context, and contesting dominant identities is often actively discouraged. According to Pendlebury (2020), this partially explains why military identities are so enduring. The explanation according to IT (Stryker (2002 [1980]), would be the individuals' commitment to the organization followed by high identity salience.

In his study on the U.S. Air Force Academy (USAFA), Pendlebury (2020) argues that efforts to achieve a representative and inclusive military are decelerated by ideal identities that value "the classical model of the heroic masculine (p. 163)." According to Pendlebury (2020), the warrior ethos is becoming less relevant as technology changes warfare, and only a small number of officers conduct duties related to active combat. An even smaller number fits the mold of a traditional warrior and reinforcing such an exclusive identity in military education may marginalize those who do not fit the frame (Pendlebury, 2020). Do and Samuels (2020) make similar observations in their study on USAFA. The Academy's official guidelines define "warrior ethos" as "tough mindedness, tireless motivation, an unceasing vigilance, [and] willingness to sacrifice one's life for the country (Do \& Samuels, 2020; USAFA, n.d., p. 1).”

Men often seem to pursue the valuation of other men when constructing their identities (Collinson, 2003). Masculine identities are typically constructed, negotiated, and achieved through a process of identifying with some men and differentiating themselves from other men and from women (Collinson \& Hearn, 1994). According to Giddens (1991), identity is reflexive, and any threat to it may create a sense of ontological insecurity, which one aims to avoid by sustaining coherent biographical narratives. Expanding on this idea, Knights and Willmott $(1989,1990)$ argue that insecurity is an existential condition of identity. The more individuals search for a stable identity and attempt to provide a sense of order, the more likely they are to be threatened by change (Knights \& Willmott, 1989, 1990). When military identities are constructed through the attempt to maintain order and the appreciation of men, female officers 
automatically become "others" who are a threat to men's sense of self and ontological security. This mechanism of othering also affects men who are, for one reason or another, considered to be outside the desired masculine military ideals.

While most Western militaries have moved away from conscription to professional armies (Moskos et al., 2000), Finland has retained conscription as a basis of national defense. This continues to be the main task of the FDF, particularly for geographical reasons. According to Leinonen et al. (2018), this has also retarded the process of professionalization in the FDF. In the following section, the national characteristics of the FDF and Finnish military identities are presented.

\section{Finnish Military Identities}

Before the cadet flag, the symbol of loyalty and bravery, honor and comradeship, I pledge to devote my work and life to the Fatherland. During my cadet years and afterwards may my objective be the liberty of Finland and the felicity of our people. May the heroic memory of our former generations remain sacred to me, and may soldier's honor be the guiding star of my activities. May the incentives to and objectives of my thoughts and actions always be noble. I will not avoid hard work, battle, suffering or death in order to fulfill this promise. May God help me remain strong on the road of honor. (The Cadet Vow, Liene, 2000, p. 52)

According to the latest Annual Report on Personnel (Defence Command, 2020), the officer corps in the FDF consists of 3007 military officers, out of which $84(2.8 \%)$ are women. The average age of the officers is 38.4 years. One of the obvious reasons for the profession of military officer being so heavily male-dominated is male-only conscription. Compulsory military service for men makes the FDF a special institution in Finnish society (Leinonen et al., 2018). Women's voluntary military service was established in Finland in 1995. It has grown in popularity over the past few years, but the number of female conscripts has remained around 3-5\% of the approximately 24,000 annual conscripts (Defence Command, 2020). Completing military service is the only pathway to a career as a professional soldier.

In 1992, 1998, 2003, and 2007, a survey was carried out among the officers of the FDF (Heinänen, 2012). These four nearly identical surveys posed questions about officers' ethical conceptions and values. Six different factors were used in the research: officer qualities, pursuit of interests and human weaknesses, idealism, professionalism, traditions, and war and killing. As reported in the 2007 survey, $80 \%$ of those surveyed considered the officer profession to be their vocation. This number was lower than in previous years. Nevertheless, vocation appeared to be the most significant reason why individuals chose a career in the military. According to Heinänen (2012), 90\% of officers reported being proud of their education and training and expressed having a strong professional identity. Solidarity and loyalty toward other officers were highly regarded among the participants, with $91 \%$ of participants supporting this claim. 
The factor called traditions described Finnish military officers' strong commitment to military traditions. Heinänen (2012) argues that the significance of officer traditions is at a turning point. The cadet vow (the significance of the cadet vow) has traditionally been seen as the most important and binding pledge for a military officer. However, the significance of the cadet in everyday life was considered controversial among the participants, and there was a clear division: $43 \%$ of them felt that they obeyed the vow, while $40 \%$ felt they did not follow it in their everyday lives (Heinänen, 2012). Heinänen also examined officers' relationship with work and leisure. He found that although officers' commitment to the institution had become weaker, their professionalism had grown. Being a soldier was considered to be more of a job like any other, rather than something that guides and defines all aspects of life.

Organizational control and normalization as forms of power are mentioned explicitly in the goals of training and education offered by the Finnish National Defence University (NDU). The General Staff Officer Course is a course for officers who aim to hold the highest positions in the military. The NDU website describes the course objectives as follows:

The specific responsibility of the Postgraduate Programme is to educate and train General Staff Officer Students to become General Staff Officers who have internalized the military behavior and norms in order to serve their country. (NDU, 2021)

It is explicitly expressed that the behavior and norms are not just performed but they are expected to be a part of the officer's personal values and identity. The institution is not satisfied with controlling the employee's professional identity but aims to create a coherent identity where professional and personal are the same entity. The process of normalization starts during military service and continues through cadet school and even in upper-level courses practiced upon officers of higher ranks. Once an individual internalizes organizational norms and values, there is no more need for external control - the individual controls themself and often other members of the same community as well.

Identity work is a necessity in almost every human activity and a significant medium as well as an outcome of organizational control (Alvesson \& Willmott, 2002). Nevertheless, the organizational regulation and molding of employee identity are balanced with other influential institutions and elements of life history. Furthermore, organizational control does not necessarily increase employee commitment and loyalty, but it may catalyze resistance (Alvesson \& Willmott, 2002).

\section{Micro-political Resistance}

Resistance in the workplace is often framed within a worker-management dialectic and understood as a negative form of disruption in an organizational setting (Davies \& Thomas, 2004). According to Thomas et al. (2004), a number of studies during the late 1980s and early 1990s suggested that workplace resistance had declined. Julkunen 
(2008) argues that collective and organized forms of workplace resistance, in particular, such as strikes, have decreased everywhere during the past decades. Sociological research on work has become more interested in more individual, subtle, secret, hidden, and unorganized forms of resistance (Julkunen, 2008). According to Julkunen (2008), there are always reasons and places for resistance; where there is power, there is resistance. Resistance enables and creates room for autonomy even though it is restricted in the workplace (Julkunen, 2008).

This study adopts poststructuralist feminist theorizing of resistance. Instead of seeing resistance as something negative, the emphasis is on a generative paradigm of individual agency (Davies \& Thomas, 2004). The agency lies in the individual challenging the prevailing organizational discourses and the gendered subject positions offered by them by presenting spaces for alternative meanings and subjectivities. Davies and Thomas (2004) call this "micro-political resistance." According to Thomas et al. (2004, p. 6), "This offers an agential self, a thinking subject with the will and capacity to resist through the reflection upon, and challenging of, the hegemonic ways of being, offered in the dominant discourse."

The concept of micro-political resistance may be used to illustrate more subtle and hidden forms of disruption, which should not be overlooked as forms of individual agency. According to Kondo (1991), small everyday practices in the workplace and resisting hegemonic ideologies usually tend to go unnoticed, even though they can be observed as political acts. Thomas et al. (2004) argue that small-scale change can trigger larger-scale changes and question the dichotomy of micro-political and collective forms of resistance.

\section{Data and Methodology}

This study reviewed 108 texts written by military officers in the FDF and thematic interviews with 12 of them. At the time of data collection, the respondents were approximately 30-40 years old and had worked in the FDF for 10-15 years. All the respondents had attended or were attending a career course at the NDU. Attending the Senior Staff Officer Course (SSOC) or applying to the General Staff Officer Course (GSOC) determines an officer's future career prospects and has a huge effect on their personal life as well. Attending the GSOC gives an officer the opportunity to reach the highest ranks of the FDF. It also means that the officer will be re-stationed in a 2-year cycle. This can cause a lot of strain on the officer's family, which is one of the most common reasons why officers choose to attend the SSOC instead of the GSOC. The SSOC lasts for 5 months, whereas the GSOC is a 2-year course.

The period during which officers ponder the question of whether to apply to the GSOC or attend the SSOC is also a time of critical reflection on one's professional identity, career aspirations, and the significance of one's family or personal life in general. At this stage of their careers, officers are about to gain more power and a more privileged position in the military hierarchy, as they become middle managers after completing either of the courses. 
Both the courses were visited and around 160 students were reached (around 80 per course) and 57 students from GSOC and 51 students from SSOC sent their short texts about the officers' conceptions of the ideal soldier to participate in this study. As a part of data collection for this study, the students were given 30 minutes to write about how they perceive themselves in relation to the ideal soldier and how their career and other aspects of their lives have influenced their conceptions. There were only a few women in the courses. Eight of the texts were written by women, while the rest $(n=100)$ were written by men. Majority of the texts were from half a page to one page long, but some consisted of a few sentences or a short list of preferred qualities for the ideal soldier.

In addition to the texts, thematic interviews were conducted with eight of the male participants and four of the female participants. The interviewees were selected based on their texts and their expressed willingness to be interviewed. A standardized interview guide was used as a starting point but also the themes that arose from the respondents' texts were discussed. The interviewees represented a wide range of different conceptions of the ideal soldier. The interviews were recorded and transcribed. The duration varied from 45 minutes to a little more than 2 hours. All responses have been translated from Finnish to English by the author.

Thematic discourse analysis (TDA) (Braun \& Clarke, 2021) was used in this study to examine what kinds of military identities were constructed in and through discourse - both dominant and resistant. Discourse analysis views language as social practice and is helpful in identifying the discursive production of personhood and subject positions (Braun \& Clarke, 2021). Through TDA socially produced patterns and themes could be identified from the data. The key themes were guided by the theoretical and conceptual choices as well as the overall research questions posed to the data. According to Braun and Clarke (2021) the phases of thematic analysis are familiarization, coding, generating initial themes, reviewing, and developing themes, refining, defining, and naming themes, and writing up - and repeat when necessary.

All of the 108 texts were reviewed, and initial discursive themes and codes were identified. The 12 transcribed interviews were used to deepen the understanding of the identified themes. The themes were then categorized into codewords according to similar content. The codewords were highlighted and counted. Based on these codewords, a prevailing discourse was identified, as well as discourses in which dominant discourses were resisted.

The quotations included in the findings section were selected from both the texts and interviews; "W" indicates a written response, while "I" indicates an interview response. Somewhat unexpectedly there were no significant differences between the responses of SSOC and GSOC students - not even concerning the balance between work and family life. Therefore, the course is not mentioned in the quotations. In terms of anonymity, the less information about the respondents was provided, the better. This concerned especially female respondents who were few in number. The presented quotations do not represent the whole data or any ideal types but serve to illustrate the prevailing discourse, discourses of micro-political resistance, and the way the respondents constructed alternative meanings and identities. 


\section{Findings}

\section{The Prevalent Discourse: The Greater Good}

Based on the emphasis presented in the data, the dominant discourse was identified as the greater good. In line with previous research (e.g., Do \& Samuels, 2020; Pendlebury, 2020), this discourse can be positioned inside the more global "warrior ethos." Many of the features that the officers attached to the notion of the ideal soldier were culturally coded as masculine and reflected the demands of the battlefield. Of the 108 total texts, 48 mentioned codewords, such as values, ethics, patriotism, the higher good, national defense, sacrifice, and loyalty. All the chosen codewords were war-related and reflected values and ethical conceptions similar to what Heinänen (2012) had discussed in his study under the factor war and killing. Many of the respondents also mentioned the cadet vow or the military oath ${ }^{1}$ as something that summarized the values and norms they attached to the ideal soldier. The military oath is traditionally considered an important milestone for conscripts in the transition from a civilian to a soldier. Both the military oath and the cadet vow express the organizational values and expectations that the soldiers are assumed to commit to and represent the official discourse of the FDF. "The longer I've worked in the FDF, the more meaningful the words in the cadet vow about sacrificing one's work and life to fatherland have become to me (Male officer, W)."

The cadet vow and the military oath express one's willingness to be a good citizen and to serve the country in any situation. In short, they embody giving up something for the higher good, for the fatherland. This discourse was undoubtedly-and unsurprisingly - the most dominant, and it expressed the strong commitment and vocation of the officers. When organizational values are internalized, they are voiced as personal values, as can be noted in the above quotation.

To even apply there [cadet school], you must have a certain set of values, and you can't be like, "me first." It means that you must... You think about what's best for your own group.

[. . .] You want to defend your fatherland and the common good. (Female officer, I)

The prevailing discourse shows the ideological conviction of those who have chosen a career in the military, as well as the successful process of normalization and identity regulation practiced by the military organization (Kümmel, 2018). The respondents explained that the ideological dimension brought meaning to their everyday work and made it easier for them to understand one another and work together. According to Alvesson and Willmott (2002), organizational identity regulation may generate feelings of belonging and a sense of community, which strengthens the commitment of the employee.

I think a soldier/an officer is, in a way, always working. The position of an officer is not something you just do at the office, but an officer is an officer also outside the workplace and office hours. (Male officer, W) 
The traditional perception is that being a professional soldier is not only what you do but also who you are. A few of the respondents voiced this traditional view and criticized those who leave work at the end of office hours instead of completing a task. This is a typical feature of the traditional warrior ethos: being a soldier is a vocation, and one must always be ready to serve one's country, even in peacetime.

Being physically fit was mentioned in 59 of the texts. Some of the respondents stated that, in their opinion, physical fitness was overemphasized as part of the ideals of the military. However, they still perceived it as part of the dominant discourse, even if they did not agree with it. In addition to the physical qualities, mental features that can be considered culturally coded as masculine were mentioned in 46 texts. Along with physical fitness, this discourse included codewords such as decision-making, courage, determination, analyticity, natural authority, emotionally in control, willingness to win, straightforward, and solution-oriented.

The traditional image of a soldier is still very masculine, and there are no good female leaders in the FDF that many steps ahead of me. That's why I easily compare myself with my male colleagues even though I know I will never be a leader like them. I will always lead and act as an officer based on my own qualities and personality traits, which are quite different from my male colleagues. At the moment, this causes me some discomfort. (Female officer, W)

I haven't been rewarded [during my career], and I've been starting to think that maybe... That I'm different [ . . ] could it be the reason that maybe I don't succeed because I'm not similar to them. (Female officer, I)

Both female respondents above felt that they did not reach the masculine ideals of the military. The latter respondent suspected that she was left unrewarded and feeling unsuccessful because of this. Three of the female interviewees who were attending the GSOC mentioned that they had discussed the course peer evaluations with other women and found that almost all of them were at the bottom end of the list. One of them compared their time in the career course to their time in cadet school. Both were competitive situations in which students strove for the best placements. The most successful students were able to choose where they would be stationed after the course; therefore, the stakes were high.

We fight for placements in this course, and some of us think, like the career-oriented ones, that peer evaluation is a good place to pull women down to enable one's own success. (Female officer, I)

Leinonen et al. (2017) noted in their research on conscripts that women who succeeded and attended leadership training were more likely to lack support from their peers. They also reported that their gender was a negative factor in terms of appreciation from their peers. Leinonen et al. (2017) speculate that women's negative experiences are related to 
the competitive setting. As noted above, a similar competitive setting appears in the cadet school, as well as in the GSOC. The female students of SSOC did not mention anything about competition or peer evaluations, which might have to do with the fact that the setting at SSOC is much less competitive than at GSOC. According to Collinson (2003), careerism intensifies highly competitive workplace cultures, and success may be a medium for men to establish masculine identities in the workplace.

The discourse on the greater good was highly gendered and included war-related traditional masculine ideals that marginalize those who do not reach the expected roles, norms, and ideals. Feelings of "otherness" may catalyze resistance, which is discussed in the following section.

\section{Discourses of Micro-Political Resistance}

A job like any other. Even though the ideological dimension of the profession was widely supported in the data, a few of the respondents criticized certain values that were part of the dominant discourse as outdated "echoes from the past." Some officers critiqued the "equalizing culture" and the concept of "uniformity" and called for open discussion with the possibility of questioning organizational values instead of taking them for granted. Codewords related to this discourse were found in 18 of the texts.

Through age, I've become more critical toward this quite exhausting equalizing culture. [...] Everyone is expected to have the same kinds of values that you cannot question - at least not out loud. You take the organizational values as a given. Period. This is often quite distressing, and there is no ongoing versatile discussion in the organization about what it is to be a soldier and the problems related to that. It's a question about a profession of which the essence per se is based on a rational and justified need to defend the country. It should be dealt with more as a job like any other, not as "a sacred calling." Because putting it on a pedestal often turns it to ponderous theatre. (Male officer, W)

As seen in the above quotation, the respondent both supported and resisted the dominant discourse. By questioning the concept of the profession as "a sacred calling," he reinforced the idea of the special nature of the profession of a military officer. However, for him, it is "a job like any other (see also, Heinänen, 2012)." The respondent located himself outside the dominant discourse and expressed distress for the subject position offered by the prevailing understanding of the profession as something that should not be criticized or even discussed openly. He felt he was not the only one who felt this way but believed that people might not necessarily say what they actually think out of fear of being stigmatized as antagonists. Another respondent suggested that people are afraid to speak their minds because of the negative effects it could have on their evaluations and future careers.

In addition to the physical ideal, other factors are also accentuated, such as the more traditional ones, trustworthiness, honesty, resilience, and patriotism, which are often 
cherished in forms of traditions. These are, of course, still important when cherishing communality, but it can be reflected how these values are manifested nowadays and if they are valued anymore in practice. The world and more precisely the society and the FDF as a part of it are changing, and it can be questioned how e.g., the miracle of the Winter War or the legacy of veterans still speak to officers and more broadly professional soldier nowadays. (Male officer, W)

This quotation shows resistance toward leaning too much on traditions and history. The respondent calls for normative change (Holmberg \& Alvinius, 2019) to correlate the society better. For him, the military organization and its culture should represent and reflect the current values instead of searching for legitimacy from previous wars. Another respondent suspected that the demands of a good soldier are actually the same as those of a good employer in any "normal organization (Norrheim-Martinsen, 2016)" and questioned the uniqueness of the military as a workplace.

Family first. The importance of family was discussed in 22 of the texts. Regardless of gender, many of the respondents felt that becoming a parent had changed their priorities, as well as their conception of the ideal soldier. As it would be phrased in IT (Stryker, 2002 [1980]), their parent identity became salient in their hierarchy of identities. They wanted to put family first, even though they assumed it would negatively affect their future careers.

The ideal officer doesn't have a family because [she/he] is always ready to move to another location or on a mission abroad if it helps her/his career. [.. . The main reason why I differ from the ideal is that I put my family first before work matters. (Male officer, W)

I put family before work. My career will crash because of this view. (Female officer, W)

Although the resistant discourse of family first occurred in the texts of both men and women, the female respondents felt there was still a difference between genders in the degree of impact having children actually has on one's career. Out of eight women, only two mentioned family in their texts, but three of the four female respondents discussed the theme quite extensively during their interviews. Some of the women had children of their own, while some did not.

It's a big choice for a woman to attend the GSOC if you have family. It's for men, too, if they have family, but it's in some way more accepted. There is still maybe this idea that women should stay at home and take care of the kids. But I have to raise my hat to these women who have made such a hard decision. (Female officer, I)

Many of the respondents expressed that they had conflicting feelings regarding the FDF's claim that family is a core value of the organization while rarely supporting officers' efforts to be present with their spouses and children in practice. It was 
especially difficult for them to decide whether to apply to the GSOC, as graduates may be expected to move around Finland and likely spend a lot of time apart from their families. However, there were no significant differences between the students from SSOC and GSOC in how much they seemed to value their family and in wanting to put family first.

In the above quotation, the respondent sees this decision as difficult for women in particular. This moves away from the traditional idea of military families where women used to take care of the children, and the whole family moved when the officer father was appointed to another occupation, implying that there is pressure on the organization to change the organizational culture. According to Holmberg and Alvinius (2019), this is challenging in terms of the greedy traits of the military organization. Segal (1986) argues that both the military and the family can be perceived as greedy institutions. This creates a conflict in which the officer's commitment and loyalty are constantly tested and in competition. As fathers become more involved in family life and parenting than they traditionally have been, this conflict will continue to grow until it is resolved by either the individual or the organization.

Being oneself. Along with the assumption that everyone who chooses a career as a military officer has a certain ideological background, some of the respondents seemed to support the idea that the educational system eliminates individuals who are "unsuited" for the profession. One of the interviewees described the process of othering through his own experiences of the cadet school.

I consider myself to have been bullied at the cadet school right from the beginning. And it went on during my career for quite a long time. Until I got to a certain kind of position, where differing from the standards or stereotypes was considered to be a forte. (Male officer, I)

The respondent stated that he felt different from other cadets and that he deviated from traditional military ideals and stereotypes. He further described himself as "not that physical or sporty" and discussed hobbies that would not be considered typically masculine. He felt there was strong group pressure in the cadet school to fit a certain mold. Despite being bullied, the respondent decided to continue his career in the military. At the micro-level, even the decision to continue his service after a negative experience in which he felt severely othered can be considered a political act. Finally, as the respondent's career reached a certain stage, he was able to turn his differences into a strength, which was useful for the organization as well as his own well-being. The features and qualities that were considered "non-masculine" in the competitive setting of the cadet school later became valued expertise. Supporting the previously mentioned critique of equalizing culture and uniformity (see discourse on $A$ job like any other above), the codeword difference appeared 23 times in the texts, described positively as something the officers had learned to appreciate more over the years. Being oneself was mentioned explicitly in 11 of the texts. 
I don't feel that I've ever fitted into this ideal, especially in terms of my behavior or physics. [. . .] I believe that different kinds of people fit in the soldier mold-the mold gives up, not one's personality. I haven't rebelled against this ideal; rather, I accepted that I can be as I am, and it doesn't mean that I'm any worse at my job. (Male officer, W)

I'm not like that, how they show on TV, that a soldier can do anything, totally callous and stuff. I'm not like that. This is how I am, if that won't do, bummer [in sarcastic tone]. (Female officer, I)

According to Thomas and Davies (2005), "being different" is a form of resistance on its own. Officers who resisted the roles and subject positions offered by the prevailing discourse and traditional military ideals stated that they had given up those demands and decided just to "be themselves." This included both men and women who felt that they did not reach the ideals or had the experience of feeling "other." For some, this may have been more of a personal choice followed by a privileged position, but for others, it was forced because they were already marginalized. Women, in particular, were "automatically" positioned outside the ideals of the dominant discourses due to their gender. According to Collinson (2003), employees who engage in resistance often construct an alternative and more positive sense of self as opposed to the one provided by the organization.

One woman doesn't affect that community of tens of people that much, but that individual just aims to adapt. At least I was just trying to be a part of the group. But maybe when there are more, then it will, in a certain way, be easier to be oneself there. (Female officer, I)

The effects of micro-political resistance were mostly visible at the individual level, in situations in which an employee was able to find a solution to the conflict between personal and organizational desires. Despite feeling the need to resist the dominant organizational identities and expectations, all the officers who participated in this study had decided to continue on their career path. The above quotation describes the possibilities of micro-political resistance when combined with solidarity and power.

\section{Discussion}

When military identities are acknowledged as situational, dynamic, and under constant change, there is space for alternative identity construction in the total institution. Even though the frame in which identity work is done is more rigid in the military than in other organizations, soldierly subjects do not necessarily construct their identities according to the roles defined by the military organization. In this study, the concept of micro-political resistance was employed to examine FDF officers' resistance at the level of discourses, identities, and meanings, when they found their personal identities 
and organizational roles in conflict. As collective professional identities are becoming more fragile (Castells, 2010) and constant change is becoming a dominant feature of postmodern militaries (e.g., Moskos et al., 2000), there seems to be more space for resistance as well as alternative identities.

From the data collected in this study, a dominant discourse (the greater good) and three micro-political discourses were identified. First, perceiving the profession of a military officer as a job like any other instead of a sacred calling that should not be openly discussed or criticized. Second, putting family first instead of work, regardless of the gender of the officer. Third, being oneself instead of performing the traditional role of a masculine warrior.

The findings show that the micro-political resistance of military officers in the FDF derives from both men's and women's experiences of being "other." Women are automatically othered in military discourse because of their gender. The feeling of otherness among men derives from personal features that somehow do not meet the norms and ideals of a military officer. These feelings of otherness force officers to search for alternative subject positions instead of adopting those offered by the prevailing organizational discourses.

The discourses of micro-political resistance identified in this study reflect changes in the norms and values of Finnish society, such as individualism and a more equal division of parenting responsibilities. When a military organization resists normative changes (Holmberg \& Alvinius, 2019) or adopts them too slowly, individuals within that organization feel the need to resolve the conflict between the norms and values. As seen in the data, the participants in this study were highly committed to the military organization and therefore needed to develop a strategy to be able to continue to work as professional officers.

Resistance to the dominant at the level of the individual subject is the first stage in the production of alternative forms of knowledge or where such alternatives already exist, of winning individuals over to these discourses and gradually increasing their social power.

(Weedon, 1993, p. 111)

To be effective in a military context, micro-political resistance calls for solidarity between officers regardless of gender and especially supporting those who are more marginalized. By engaging in collective acts of solidarity and by gaining more power in the organizational hierarchy, officers who are changing meanings at the microlevel might also act as change agents in terms of the organizational culture of the military. This study participates in the discussion concerning military identities and presents insight into the ways relatively enduring military identities could be challenged and changed. It is most directly applicable to other Nordic militaries with conscription and a common framework of welfare society (see, e.g., Johansen et al., 2014). Perhaps even more interesting would be to examine how micro-political resistance is enacted within professional militaries. 


\section{Acknowledgements}

The author would like to thank Aida Alvinius and the anonymous reviewers for their thoughtful and encouraging comments.

\section{Declaration of Conflicting Interests}

The author(s) declared no potential conflicts of interest with respect to the research, authorship, and/or publication of this article.

\section{Funding}

The author(s) received no financial support for the research, authorship, and/or publication of this article.

\section{ORCID iD}

Suvi Kouri (D) https://orcid.org/0000-0003-3578-096X

\section{Note}

1. I (N. N.) promise and affirm before the almighty and all-knowing God/by my honor and by my conscience that I am a trustworthy and faithful citizen of the state of Finland. I want to serve my country honestly and, to my best ability, seek and pursue her edification and advantage. I want everywhere and in every situation, during peace and during war, to defend the inviolability of my country, her legal system of government and the legal authority of the Republic. If I perceive or gain knowledge of activity to overthrow the legal authority or to subvert the system of government of the country, I want to report it to the authorities without delay. The unit to which I belong and my place in it I will not desert in any situation, but so long as I have strength in me, I will completely fulfil the task I have received. I promise to act honorably and with integrity, obey my superiors, comply with laws, and decrees and keep the service secrets entrusted to me. I want to be forthright and helpful to my fellow service members. Never will I due to kinship, friendship, envy, hatred, or fear nor because of gifts or for any other reason act contrary to my duty. If I am given a position of command, I want to be just to my subordinates, to take care of their well-being, acquire information on their wishes, to be their mentor and guide and, for my part, set them a good and encouraging example. All this I want to fulfil according to my honor and my conscience. (Defence Command, 2017, p. 274.)

\section{References}

Alvesson, M., \& Willmott, H. (2002). Identity regulation as organizational control: Producing the appropriate individual. Journal of Management Studies, 39(5), 619-644. https://doi.org/10. $1111 / 1467-6486.00305$.

Braun, V., \& Clarke, V. (2021). Can I use TA? Should I use TA? Should I not use TA? Comparing reflexive thematic analysis and other pattern-based qualitative analytic approaches. Counselling and Psychotherapy Research, 21(1), 37-47. https://doi.org/10.1002/capr. 12360. 
Castells, M (2010). The power of identity (2nd ed.). Wiley-Blackwell.

Collinson, D. L. (2003). Identities and insecurities: Selves at work. Organization, 10(3), 527-547. https://doi.org/10.1177\%2F13505084030103010.

Collinson, D., \& Hearn, J. (1994). Naming men as men: Implications for work, organization and management. Gender, Work \& Organization, 1(1), 2-22. https://doi.org/10.1111/j.14680432.1994.tb00002.x.

Davies, A., \& Thomas, R. (2004). Gendered identities and micro-political resistance in public service organizations. In R. Thomas, A. Mills, \& J. Helms Mills (Eds.), Identity politics at work. Resisting gender, gendering resistance (pp. 86-101). Routledge.

Defence Command. (2017). Soldier's guide. Defence Command, General Headquarters. https:// puolustusvoimat.fi/documents/1948673/2267766/SK2017_ENG_1r/07c5b6d8-041b-4370aa60-3e7bbad19399/SK2017_ENG_lr.pdf.

Defence Command. (2020). Henkilöstötilinpäätös. [Annual report on personnel]. Defence Command, General Headquarters. https://puolustusvoimat.fi/documents/1948673/2267037/ Puolustusvoimien thenkil\%C3\%B6st\%C3\%B6tilinp\%C3\%A4\%C3\%A4t\%C3\%B6s+2020. pdf/cdf9d405-e3fe-7af2-3110-b338e5b5055f/Puolustusvoimien+henkil\%C3\%B6st\%C3\% B6tilinp\%C3\%A4\%C3\%A4t\%C3\%B6s+2020.pdf?t=1617172907657.

Do, J. J., \& Samuels, S. M. (2020). I am a warrior: An analysis of the military masculine-warrior narrative among U.S. Air force officer candidates. Armed Forces \& Society, 47(1), 25-47. https://doi.org/10.1177\%2F0095327X20931561.

Giddens, A. (1991). Modernity and self-identity: Self and society in the late modern age. Stanford University Press.

Goffman, E. (1961). Asylums: Essays on the social situation of mental patients and other inmates. Penguin Books.

Heinänen, J. (2012). Upseerien arvotutkimus 2007. In T. Sirén (Ed.), Upseerina 100-vuotiaassa Suomessa. Millä arvoilla muutoksen maailmassa? [As an officer in 100-year-old Finland. With what kinds of values in the changing world?. Maanpuolustuskorkeakoulun Johtamisen laitoksen Julkaisusarja 2. Artikkelikokoelmat 20/2008 (pp. 7-30). Maanpuolustuskorkeakoulun Johtamisen laitos ja Kadettikunta ry.

Holmberg, A., \& Alvinius, A. (2019). How pressure for change challenge military organizational characteristics. Defence Studies, 19(2), 130-148. https://doi.org/10.1080/14702436.2019. 1575698 .

Janowitz, M. (1960). The professional soldier: A social and political portraitGlencoe (Ill.). Free Press.

Johansen, R. B., Laberg, J. C., \& Martinussen, M. (2014). Military identity as Predictor of perceived military competence and skills. Armed Forces \& Society, 40(3), 521-543. https:// doi.org/10.1177\%2F0095327X13478405.

Julkunen, R. (2008). Uuden työn paradoksit. Keskusteluja 2000-luvun työprosesseista [The paradoxes of new work. Debates on the labor processes in the 21st century]. Tampere.

Knights, D., \& Willmott, H. (1989). Power and subjectivity at work: from degradation to subjugation in social relations. Sociology, 23(4), 535-558.

Knights, D., \& Willmott, H. (1990). Labour process theory. Macmillan. 
Kondo, D. (1991). Crafting selves: Power, gender and discourses of identity in a Japanese workplace. University of Chicago Press.

Kümmel, G. (2018). Military identity and identity within the military. In G. Caforio, \& M. Nuciari (Eds.), Handbook of the sociology of the military (2nd ed., pp. 477-493). Springer International Publishing.

Leinonen, M., Nikkanen, R., \& Otonkorpi-Lehtoranta, K. (2018). Organizational change and employee concerns in the finnish defence forces. Nordic Journal of Working Life Studies, 8(3), 135-153. https://doi.org/10.18291/njwls.v8i3.109544.

Leinonen, M., Otonkorpi-Lehtoranta, K., \& Nikkanen, R. (2017). Naisten ja miesten osallisuus ja vuorovaikutus asepalveluksessa tasa-arvon näkökulmasta [The participation and interaction of women and men in military service from the equality point of view]. Tampere: University of Tampere. https://trepo.tuni.fi/bitstream/handle/10024/102294/WP_ty\%C3\% B6raportti\%2096\%202017.pdf?sequence $=1$.

Liene, T. (2000). Hands on the hilt. A brief history of Finnish officer training. National Defence College's Department of War History.

Moskos, C. C. (1977). From institution to occupation. Trends in military organization. Armed Forces and Society, 4(I), 41-50. https://doi.org/10.1177\%2F0095327X7700400103.

Moskos, C. C., Williams, J. A., \& Segal, D. R. (Eds.), (2000). The postmodern military: Armed forces after the Cold War. Oxford University Press.

National Defence University. (2021). Postgraduate programme. https://maanpuolustuskorkeakoulu. fi/en/postgraduate-programme.

Norheim-Martinsen, P. M. (2016). New sources of military change - Armed forces as normal organizations. Defence Studies, 16(3), 312-326. https://doi.org/10.1080/14702436.2016. 1195234.

Pendlebury, J. (2020). "This is a man's job": Challenging the masculine "warrior culture" at the U.S. Air force Academy. Armed Forces \& Society, 46(1), 163-184. https://doi.org/10. 1177\%2F0095327X18806524.

Segal, M. W. (1986). The military and the family as greedy institutions. Armed Forces \& Society, 13(1), 9-38. https://doi.org/10.1177\%2F0095327X8601300101.

Stets, J. E., Burke, P. J., Serpe, R. T., \& Stryker, R. (2020). Getting identity theory (IT) right. Group Processes, 37, 191-212. https://doi.org/10.1108/S0882-614520200000037007.

Stryker, R. (2002 [1980]). Symbolic interactionism: A social structural version. The Blackburn Press.

Thomas, R., \& Davies, A. (2005). Theorizing the micro-politics of resistance: New public management and managerial identities in the UK public services. Organization Studies, 26(5), 683-706. https://doi.org/10.1177\%2F0170840605051821.

Thomas, R., Mills, A. J., \& Helms Mills, J. (2004). Introduction: Resisting gender, gendering resistance. In R. Thomas, A. Mills, \& J. Helms Mills (Eds.), Identity politics at work. Resisting gender, gendering resistance (pp. 1-19). Routledge.

USAFA. (n.d.). Warrior ethos as airmen and citizens. https://www.usafa.edu/app/uploads/ Warrior-Ethos-White-Paper-approved.pdf.

van Dijk, T. A. (1996). Discourse, power and access. In C. R. Caldas-Coulthard, \& M. Coulthard (Eds.), Texts and practices: Readings in critical discourse analysis (pp. 84-104). Routledge. 
Weedon, C. (1993). Feminist practice and poststructuralist theory (2nd edn). Blackwell.

Woodward, R., \& Jenkings, K. N. (2011). Military identities in the situated accounts of British military personnel. Sociology, 45(2), 252-268. https://doi.org/10.1177\% 2F0038038510394016.

\section{Author Biography}

Suvi Kouri is a doctoral researcher in sociology at the University of Jyväskylä (Finland) and a former military chaplain of the Finnish Defence Forces. Her research interests include gender and military, the notion of the ideal soldier and transformations of military culture. 